2021:6(2):44-48

http://ojs.uho.ac.id/index.php/JIA

doi: http://dx.doi.org/10.37149/JIA.v6i2.16253

\title{
ANALISIS PERILAKU KONSUMEN TERHADAP KEPUTUSAN MEMBELI PRODUK TANAMAN ORGANIK DI KEBUN FAKULTAS PERTANIAN UNIVERSITAS NUSA NIPA
}

\author{
Theresia Maria Elisabeth $^{1^{*}}$, Sarlina Noni ${ }^{1)}$, Yoseph Yakob Da Rato \\ ${ }^{1}$ Program Studi Agribisnis, Universitas Nusa Nipa \\ *Corresponding author: newartheresia@gmail.com
}

To cite this article:

Elisabeth, T., Noni, S., \& Da Rato, Y. (2021). Analisis Perilaku Konsumen terhadap Keputusan Membeli Produk Tanaman Organik di Kebun Fakultas Pertanian Universitas Nusa Nipa. JIA (Jurnal Ilmiah Agribisnis) : Jurnal Agribisnis dan IImu Sosial Ekonomi Pertanian, 6(2), 44 - 48. doi:http://dx.doi.org/10.37149/jia.v6i2.16253

Received: January 27, 2021; Accepted: March 20, 2021; Published: March 25, 2021

\begin{abstract}
Organic agriculture is becoming the newest agricultural sector high Community, and changes in developed and developing countries pay attention to health and the environment. The market of organic farm products is experiencing an increase in the world due to market demand. People today have healthy lifestyle habits that have become a measure of quality. To achieve a balance between busyness and exercise and regularly Eating food can start a healthy life. The further away the food contains chemical drugs or pesticides, the more likely it is to open a beneficial standard of living. This study aimed to analyze the behavior of buyers towards the decision to buy organic plant products in the garden of the Faculty of Agriculture, University of Nusa Nipa Maumere. This research was conducted from 01 October to 01 November 2020. The data collection technique used interviews made observations and filled out a questionnaire prepared by the researcher. Several thirty respondents were interested in data through the purposive sampling technique. The data analysis of this research used the Simple Linear Regression and t-test. The results obtained are the relationship between consumer behavior and the decision to buy an organic plant product has a significant effect, with the strength of the relationship between consumer behavior variables and the decision to purchase organic plant products is very strong and positive, meaning that if consumer behavior is improved, the decision to buy plant products organic also increases
\end{abstract}

Keywords: buying decisions; consumer behavior; organic; organic plants

\section{PENDAHULUAN}

Pertanian organik menjadi sektor pertanian terbaru tinggi Komunitas dan perubahan di negara maju dan berkembang memperhatikan tingkat kesehatan dan lingkungan. Pasar hasil pertanian organik mengalami peningkaan didunia diakibatkan oleh permintaan pasar. (Hubeis, 2013; Parlyna \& Munawaroh, 2011). Pola hidup lingkungan masyarakat yang memperhatikan kualitas kesehatan manusia dan lingkungan. Karena potensi pertanian organik yang sangat besar, banyak negara di dunia mulai menekuni pertanian organik (Khorniawati, 2014; Parlyna \& Munawaroh, 2011). Dalam rangka pemenuhan kebutuhan akan suatu produk pertanian, konsumen harus mempertimbangkan beberapa atribut saat membandingkan produk makanan organik dan produk makanan non-organik. Beberapa alasan konsumen membeli Makanan organik lebih banyak karena konsumen menganggap makanan organik Lebih sehat dari makanan non-organik. Perbedaan persepsi ini didasarkan pada tingkat pengetahuan dan kesadaran tentang kebiasaan atau pola belanja konsumen Konsumen dan makanan organik ada atau ada faktor (Khorniawati, 2014). Ketidakseimbangan yang serius antara penawaran dan permintaan di pasar disebabkan oleh kesalahpahaman tentang preferensi konsumen dan faktor kunci yang mempengaruhi penerimaan organik produk makanan di pasar, yang merupakan kendala yang sangat penting untuk pengembangan lebih lanjut produksi makanan organik (Melovic et al., 2020).

Kebun Fakultas Pertanian Universitas Nusa Nipa dalam membudidayakan tanaman organik yang mana Kebun Fakultas Pertanian Universitas Nusa Nipa Maumere ini merupakan fasilitas lahan yang digunakan mahasiswa untuk praktek penelitian dan Kebun berbasis Agro Wisata yang dimana 
semua Produk Tanaman Organik dapat dibeli ataupun dipasarkan kepada masyarakat melalu pasarpasar tradisional yang ada di kota Maumere kabupaten Sikka. Beberapa tanaman organik yang berhasil dibudidayakan yaitu diantaranya tanaman hortikultura, yang terdiri dari buah, sayuran. Beberpa jenis tanaman yang diproduksi adaah semangka, mentimun, terung, tomat, bawang merah dan sawi. Dalam kaitannya dengan pemasaran produk tanaman organik di atas, Kebun Fakultas Pertanian Universitas Nusa Nipa masih terbilang baru di Kota Maumere Kabupaten Sikka. Kebun Fakultas Pertanian Universitas Nusa Nipa ini menjangkau pasar di wilayah Maumere Kabupaten Sikka, produk tanaman organik ini selain dapat dibeli langsung oleh masyarakat sekitar juga di pasarkan ke beberapa Pasar Tradisional di Kota Maumere juga dipasarkan langsung pada Karyawan/i di Universitas Nusa Nipa Maumere. Konsumen dapat menjadi agen promosi utama produk dari Kebun Praktek adalah konsumen dari kelas bawah sampai kelas atas dengan tidak memperhatikan tingkat pendidikan.

Terdapat perbedaan pandangan tentang proses penentuan suatu keputusan oleh pembeli, dengan melakukan berbagai macam pertimbangan secara logis berupa pembandingan pilihan beserta harga, sehingga dapat mencapai kesepakatan dan akan memuaskan pihak konsumen seuai waktu yang dihabiskan (Rahmawati et al., 2018). Beberapa factor yang diprediksi memiliki pengaruh atas keputusannya untuk membeli produk organik, yaitu kualitas akan produk tersebut yang memiliki korelasi terhadao daya dukung bidang kesehatan dan gaya hidup manusia (Melovic et al., 2020; Rahmawati et al., 2018). Tujuan penelitian ini adalah menganalisis perilaku konsumen terhadap keputusan membeli produk tanaman organik di Kebun Fakultas Pertanian Universitas Nusa Nipa Maumere.

\section{MATERI DAN METODE}

Penelitian berlangsung di Kebun Fakultas Pertanian Universitas Nusa Nipa Maumere, Kecamatan Alok Kabupaten Sikka Provinsi Nusa Tenggara Timur (NTT). Waktu Penelitian dilaksanakan pada tanggal 01 Oktober sampai dengan 01 November 2020. Variabel bebas (independent variable) yaitu: Perilaku Konsumen $(\mathrm{X})$ dengan indikator pengetahuan, kebiasaan, status sosial, motivasi dan persepsi sedangkan Variabel terikat (dependent variable) Keputusan Membeli (Y). Kuisioer yang disiapkan diberikan koresponden, dengan beberapa pertanyaan dengan jawaban mengacu pada skala likert dalam penginputan nilai suatu jawaban. Sugiyono, (2012) skala likert digunakan untuk mengukur pendapat, dan persepsi orang tentang fenomena sosial. Analisis yang digunakan adalah Analisa Regresi Linear Sederhana yang di adaptasi (Chrysanthini et al., 2018; Sarjono \& Julianita, 2011). Model analisis regresi linear sederhana, model ini digunakan untuk mengetahui pengaruh pengaruh secara kuantitatif dari perubahan variabel yang satu terhadap variabel yang lainnya (Sugiyono, 2013). Selanjutnya data diuji Analisis Koefisien Korelasi Pearson Untuk mengetahui kuat tidaknya pengaruh antara variabel independen (bebas) terhadap variabel dependen (terikat). Selanjutnya analisis determinasi untuk menghitung kontribusi variable $\mathrm{x}$ terhadap variabel y (Sarjono \& Julianita, 2011).

\section{HASIL DAN PEMBAHASAN}

\section{Karakteristik Responden}

Responden (30 orang) yang berasal dari masyarakat yang membeli hasil produk tanaman organik pada Kebun Fakultas Pertanian Universitas Nusa Nipa Maumere. Masyarakat pembeli dan pengkonsumsi produk tanaman organik di Kebun Fakultas Pertanian Universitas Nusa Nipa didominasi oleh usia 31-40 tahun sekitar $67 \%$. Sedangkan kategori jenis kelamin terdistribusi berjenis kelamin perempuan sebanyak 20 orang $(66,67 \%)$ dan pria 10 orang $(33,33 \%)$ (Tabel 1$)$.

Tabel 1. Karakteristik konsumen produk tanaman organik di kebun Fakultas Pertanian Universitas Nusa Nipa Berdasarkan Usia

\begin{tabular}{lrrr}
\hline & Deskripsi & Jumlah & Persetase (\%) \\
\hline Usia & & & \\
& $20-30$ & 14 & 46,67 \\
$31-40$ & 20 & 66,67 \\
$41-50$ & 2 & 6,67 \\
$51-60$ & 5 & 16,67 \\
\hline
\end{tabular}


Tabel 1. Karakteristik konsumen produk tanaman organik di kebun Fakultas Pertanian Universitas Nusa Nipa Berdasarkan Usia

\begin{tabular}{lrr}
\hline \multicolumn{1}{c}{ Deskripsi } & Jumlah & Persetase (\%) \\
\hline Jenis Kelamin & & \\
Laki-laki & 10 & 33,33 \\
Perempuan & 20 & 66,67 \\
\hline Pekerjaan & 2 & \\
Pelajar / Mahasiswa & 12 & 6,67 \\
Karyawan & 6 & 40 \\
Pegawai Swasta / Wiraswasta & 4 & 20 \\
Pegawai Negeri Sipil & 6 & 13.33 \\
Lain-lain & & 20 \\
\hline Pendidikan & 2 & 0,67 \\
SD & 3 & 10 \\
SLTP & 9 & 30 \\
SLTA & 5 & 16,67 \\
Diploma & 9 & 30 \\
S1 & 2 & 6,67 \\
S2 \& S3 & & \\
\hline
\end{tabular}

Karaktersistik dibidang pekerjaan adalah Karyawan Unipa sebanyak 12 orang (40\%)) sedangkan dibidang pendidikan didominasi oleh tingkat pendidikan SMA dan S1 masing-masing 30\% disusul diploma $16,67 \%$, SLTP $10 \%$, S2 dan S3 6,67\%, dan SD 0,67\%. Menurut penelitian Chrysanthini et al., (2018) melaporkan bahwa demografi pembeli terbesar dalam pemilihan tanaman organik adalah wanita, hal ini sesuai dengan kajian penelitian ini yang menempatkan wanita sebagai pembeli terbanyak dengan total 66,67\% didukung penelitian Melovic et al., (2020) menempatkan gender kategori wanita sebagai pembeli terbanyak. Sedangkan untuk demografi jenis usia Chrysanthini et al., (2018) menempatkan Preferensi rentang usia 20-35 tahun yang menjadi konsumer terbanyak hal ini sejalan dengan kajian penelitian ini yang menempatkan pautan usia 31-40 menempati posisi tertinggi dengan persentase 67\%. Hal ini berbalik dengan penelitian (Devi \& Hartono, 2016) yang melaporkan bahwa faktor usia tidak mempengaruhi proses pemilihan suatu produk.

\section{Perilaku Konsumen dan Keputusan Membeli}

Perilaku konsumen berdampak positip terhadap keputusan membeli, sesuai perhitungan atau uji dengan menggunakan SPSS 20, yaitu uji t, yang mana hasilnya adalah Berdasarkan hasil perhitungan untuk variabel perilaku konsumen diperoleh : 4.854 sehingga Ho ditolak, ditemukan bahwa secara signifikan Perilaku konsumen memiliki pengaruh terhadap keputusan membeli. Jika perilaku konsumen ditingkatkan sebesar satu-satuan maka kepuasan masyarakat meningkat sebesar 1.551,862. Sebanyak 30 responden yang diberikan kuisioner menunjukan nilai kolerasi sebesar 0.676 , sehingga disimpulkan bahwa perilaku konsumen $(X)$ memiliki pengaruh terhadap keputusan dengan nilai korelasi yang sangat kuat berada diantara $(0,60-0,799)$. Kontribusi variabel $x$ terhadap variabel $y$, peneliti menggunakan rumus koefisien determinasi.Besarnya pengaruh perilaku konsumen terhadap keputusan membeli adalah $45,70 \%$ sedangkan $54,30 \%$ dipengaruhi oleh faktor lain diluar dari variabel penelitian. Berdasarkan wawancara secara terpisah dengan responden bahwa perilaku konsumen berdampak pada keputusan membeli yang dibuktikan dengan peningkatan hasil penjualan atau banyaknya jumlah uang yang dibawah pulang ke rumah.

Tabel 2. Hasil uji t

\begin{tabular}{|c|c|c|c|c|c|}
\hline \multirow{2}{*}{ Model } & \multicolumn{2}{|c|}{ Unstandardized Coefficients } & $\begin{array}{l}\text { Standardized } \\
\text { Coefficients }\end{array}$ & \multirow[t]{2}{*}{$\mathrm{t}$} & \multirow{2}{*}{ Sig. } \\
\hline & $B$ & Std. Error & Beta & & \\
\hline (Constant) & 1.551 & 7.047 & & .220 & .827 \\
\hline 1 Perilaku & .862 & .178 & .676 & 4.854 & .000 \\
\hline
\end{tabular}

Data dari tabel di atas, kolom B pada Constant (a) adalah 1.551 sedangkan nilai perilaku konsumen (b) adalah 0.862 , Sehingga persamaan regresinya adalah 


$$
\begin{array}{rlrl} 
& Y & =1.551+0.862 X \\
\text { Jika } X=1 & \mathrm{Y} & =1.551+0.862 X(1) \\
& =1.551,862 \\
\mathrm{X}=2 & \mathrm{Y} & =1.551+0.862 \times(2) \\
& =1.552,724 \\
\mathrm{X}=3 & \mathrm{Y} & =1.551+0.862 \times(3) \\
& =1.553,586
\end{array}
$$

Tabel 3. Hasil korelasi perilaku konsumen terhadap keputusan membeli

\begin{tabular}{llrc}
\hline \multicolumn{2}{c}{ Deskripsi } & Keputusan Membeli & Perilaku \\
\hline \multirow{2}{*}{ Pearson Correlation } & Keputusan Membeli & 1.000 & .676 \\
\cline { 2 - 4 } & Perilaku & .676 & 1.000 \\
\hline \multirow{2}{*}{ Sig. (1-tailed) } & Keputusan Membeli &. & .000 \\
\cline { 2 - 4 } & Perilaku & .000 &. \\
\hline \multirow{2}{*}{$\mathrm{N}$} & Keputusan Membeli & 30 & 30 \\
\cline { 2 - 4 } & Perilaku & 30 & 30 \\
\hline
\end{tabular}

Tabel 4. Nilai Variabel Perilaku Konsumen

$\begin{array}{cc}\text { Variabel } & \text { Nilai } \\ \text { Pengetahuan } & 3,38 \\ \text { Kebiasaan } & 3,5 \\ \text { Status Sosial } & 2,85 \\ \text { Motivasi } & 4,03 \\ \text { Persepsi } & 3,99\end{array}$

Indikator yang ada dalam perilaku konsumen, sesuai jawaban responden, rata-rata semua responden menjawab setuju (Tabel 4), hal ini dapat dikatakan bahwa perilaku konsumen memiliki pengaruh yang baik dalam membantu tenaga kerja untuk menerapkan teknologi pertanian yang diberikan, yang mana dapat membantu tenaga kerja dalam proses produksi pertaniannya, serta berdampak pada peningkatan produksi pertanian dan pendapatan. Indikator yang tergabung dalam keputusan membeli, sesuai jawaban responden rata-rata semua responden menjawab setuju (Tabel 4), hal ini dapat dikatakan bahwa faktor di dalam usaha tani atau di luar usahatani juga dapat mempengaruhi peningkatan pendapatan bagi para produsen. Salah satu motivasi terbesar masyarakat dalam membeli suatu produk adalah manfaat kesehatan dan manfaat lingkungan (Persaud Ajax \& Schillo Sandra R., 2017; Seegebarth Barbara et al., 2016). Penelitian Engel et al., (2012) menegaskan Perilaku konsumen didefinisikan sebagai tindakan berpartisipasi untuk memperoleh, mengonsumsi produk serta suatu layanan, proses pengambilan keputusan sebelumsesudah aksi. Keputusan ini didapatkan dengan berbagai pertimbangan. Penelitian Vietoris et al., (2016) melaporkan bahwa beberapa alasan utama membeli suatu produk adalah pengetahuan produk, sikap terhadap makanan organik, pengalaman, status kesehatan Anggota rumah tangga, pendapatan responden, harga produk, tempat penjualan. Poin utama keputusan pembeli makanan organik adalah nilai kandungan nutrisinya lebih tinggi dari pada sayuran tradisional, sehingga perlu diperhatikan, dan konsumen sebaiknya mempertimbangkan kualitas produk dan manfaat kesehatan, serta majalah/surat kabar adalah sumber informasi utama (Chrysanthini et al., 2018). Kepuasan akan suatu produk akan memebrikan dampak pemahaman konsep yang tinggi (Bare et al., 2021). Hal ini sesuai dengan karakteristik responden dimana prefresnsi tertinggi jenjang pendidikan pada tingkat $\mathrm{S} 1$ dan SMA sehingga mempengaruhi pengetahuan akan suatu komponen. Penelitian ini mendapatkan dukungan kajian Melovic et al., (2020) yang melaporkan bahwa tinggal S1 menjadi salah satu yang tertinggi dalam pengambilan keputusan untuk membeli produk. Selanjutnya pada data komponen pengetahuan (Tabel 4) pengetahuan mendapatkan nilai setuju sehingga dapat dikatakan bahwa pengetahuan sebagai salah satu indikator utama dalam proses pemilihan produk. Hal ini didukung oleh penelitian Devi \& Hartono, (2016) yang menjelaskan bahwa factor pendidikan merupakan fator penting dalam mengambil suatu keputusan.

\section{KESIMPULAN}

Kesimpulan yang diperoleh adalah hubungan yang signifikan (berarti) antara variabel perilaku konsumen terhadap keputusan membeli produk tanaman organik. Masing-masing variabel perilaku konsumen memiliki hubungan positif atau searah dengan variabel keputusan membeli produk 
tanaman organik, yang berarti bahwa jika perilaku konsumen meningkat maka keputusan membeli produk tanaman organik organik di Kebun Fakultas Pertanian Universitas Nusa Nipa Maumere juga meningkat.

\section{REFERENSI}

Bare, Y., Putra, S. H. J., Bunga, Y. N., Mago, O. Y. T., S, M., \& Boli, Y. T. (2021). Implementasi Biology Club I di SMA Karitas Watuneso, Kecamatan Lio Timur, Kabupaten Ende. Jurnal ABDINUS: Jurnal Pengabdian Nusantara, 4(2), 321-328. https://doi.org/10.29407/ja.v4i2.15286

Chrysanthini, B., Sumarwan, U., \& Rifin, A. (2018). Preferensi Konsumen terhadap Produk Sayuran Organik (Studi Kasus Konsumen UD Fabela-Myfarm) di Bogor Jawa Barat. MANAJEMEN IKM: Jurnal Manajemen Pengembangan Industri Kecil Menengah, 12(2), 151. https://doi.org/10.29244/mikm.12.2.151-160

Devi, S. R. M., \& Hartono, G. (2016). Faktor-Faktor Yang Mempengaruhi Keputusan Konsumen Dalam Membeli Sayuran Organik. Agric, 27(1), 60. https://doi.org/10.24246/agric.2015.v27.i1.p60-67

Engel, J. F., Blackwell, P. W., \& Miniard, P. W. (2012). Consumer Behavior. Cengage Learning.

Hubeis, M. (2013). Prospek Pangan Organik Bernilai Tambahan Tinggi Berbasih Petani. PT Penerbit ITB.

Khorniawati, M. (2014). Produk Pertanian Organik Di Indonesia: Tinjauan Atas Preferensi Konsumen Indonesia Terhadap Produk Pertanian Organik Lokal. 2, 12.

Melovic, B., Cirovic, D., Dudic, B., Vulic, T. B., \& Gregus, M. (2020). The Analysis of Marketing Factors Influencing Consumers' Preferences and Acceptance of Organic Food ProductsRecommendations for the Optimization of the Offer in a Developing Market. Foods, 9(3), 259. https://doi.org/10.3390/foods9030259

Parlyna, R., \& Munawaroh, M. (2011). Konsumsi Pangan Organik: Meningkatkan Kesehatan Konsumen? Econosains Jurnal Online Ekonomi dan Pendidikan, 9(2), 157-165. https://doi.org/10.21009/econosains.0092.06

Persaud Ajax, \& Schillo Sandra R. (2017). Purchasing organic products: Role of social context and consumer innovativeness. Marketing Intelligence \& Planning, 35(1), 130-146. https://doi.org/10.1108/MIP-01-2016-0011

Rahmawati, N. A., Suroso, A. I., \& Ramadhan, A. (2018). Factors Influencing The Purchase Intention in Online Organic Fruit and Vegetable Stores. Jurnal Manajemen Dan Agribisnis. https://doi.org/10.17358/jma.15.3.209

Sarjono, H., \& Julianita, W. (2011). SPPS vs LISREL: Sebuah Pengantar, Aplikasi untuk Riset. Salemba Empat.

Seegebarth Barbara, Behrens Stefan Henrik, Klarmann Christiane, Hennigs Nadine, \& Scribner Lisa Luebbehusen. (2016). Customer value perception of organic food: Cultural differences and cross-national segments. British Food Journal, 118(2), 396-411. https://doi.org/10.1108/BFJ07-2015-0235

Sugiyono. (2012). Metode Penelitian Kuantitatif, Kualitatif, dan Kombinasi (Mixed Methods). Alfabeta.

Sugiyono. (2013). Metode Penelitian Pendidikan: Pendekatan Kuantitatif, Kualitatif, dan $R$ \& D. Alfabeta.

Vietoris, V., Kozelova, D., Mellen, M., Chrenekova, M., Potclan, J., Fikselova, M., Kopkas, P., \& Horska, E. (2016). Analysis of Consumer's Preferences at Organic Food Purchase in Romania. Polish Journal of Food and Nutrition Sciences, 66(2), 139-146. https://doi.org/10.1515/pjfns-2015-0028 